\title{
Forest Grazing in the South
}

\author{
HAROLD E. GRELEN
}

Highlight: Potential forage production is higher in the South than in other range areas of the United States, although actual production is declining rapidly due to accelerated pine regeneration. The cutover longleaf (Pinus palustris Mill.) pinelands that produced an abundance of forage have been largely regenerated with fast-growing slash (P. elliottii Engelm.) and loblolly pines ( $P$. taed $a$ L.) and these young plantations reduce herbage production drastically within a few years. Few large industrial timber companies encourage grazing, although some allow it, often without fee, as a public relations gesture. Cattlemen who depend on forest range alone seldom own the land their cattle graze, often lease the land under an annual permit, and have little incentive to improve the range. Attempts to promote cooperation among livestock producers through grazing associations have generally been unsuccessful. Public land managers are under pressure from wildlife and environmental organizations to prohibit or curtail grazing. Operational-scale multiple-use research is needed to evaluate compatibility of cattle, wildlife, and other resources.

Range management information for southern pine forests most frequently originates at research installations and does not reflect the average pineywoods grazing operation. The South's rapid and abundant forage production has been reduced by widespread pine regeneration and other factors. Moreover, forest grazing faces growing opposition from wildlife and environmental organizations. This paper is an attempt to provide a realistic appraisal of southern range management.

\section{History}

Cattle have grazed the southern pineywoods since Spanish explorers brought them to Florida in the 16th century. Livestock numbers multiplied with increases in the number of homesteads and the establishment of large cropland plantations throughout the South. The Civil War decimated cattle numbers, but cattle production soon recovered and became important in the southern economy. By the turn of the century, longleaf pine forests of the Coastal Plain were important to cattle production (Lewis 1974).

When large-scale lumbering began about 1890, annual burning to keep the understory open and "freshen" the native forage was an established custom. Forage increased as more and more timberland was clearcut, and annual fires kept the grasses vigorous while destroying pine and hardwood reproduction. Most of the old-growth longleaf pine was harvested by 1933. Land was virtually abandoned by the lumber companies after timber harvests were completed, and millions of acres of prairie-like cutover land became "open range." All land that was not fenced was legally available to all cattlemen for live-

The author is principal range scientist, U.S. Forest Service, Southern Forest Experiment Station, 2500 Shreveport Highway, Pineville, Louisiana.

Manuscript received July 26, 1977 stock grazing. Local cattle auctions began in the South during the 1930's, giving an added impetus to the industry. The first major governmental regulation of cattle in the South came with the efforts to eradicate tick fever. Required quarantine and dipping provoked vigorous, often violent, opposition but proved effective in eliminating the disease from the South before World War II (Van Houweling 1956).

Hogs were allowed to graze the unfenced range and a large population, mostly feral, developed and was managed even more loosely than open-range cattle. Along with annual fires, hogs devastated early plantings and prevented longleaf pine from reestablishing naturally. Hogs still threaten longleaf pine regeneration in some areas.

Initially, forestry interests were unconcerned about the cutover lands, but legislation enacted at state and national levels insured the eventual restoration of the southern pineries. In 1891, Congress gave the President the power to create forest reserves on public land. These forest reserves later became National Forests. Timber companies began reforestation as early as 1912 but the annual fires that accompanied grazing on cutover lands destroyed many young plantations. By 1927 most southern states had outlawed forest arson and provided for the creation of state forestry agencies to enforce fire prevention. During the late 1920's and early 1930's, when all burning was officially discouraged, the benefits of controlled fire were being demonstrated. Inman Eldridge, Roland Harper, and $\mathrm{H}$. $\mathrm{H}$. Chapman promoted fire for fuel reduction, hardwood control, and seedbed preparation. In 1935 the Forest Service began large-scale administrative studies of prescribed burning, which led eventually to the adoption of prescribed burning as a silvicultural tool. Until World War II the Forest Service and State forestry organizations did not have enough of the right kind of tractor-fire plows or transports to fight wildfires or apply needed prescribed fires (Riebold 1971).

After World War II most of the cutover lands that had belonged to the cut-and-get-out lumber companies were acquired by large, stable timber companies. Pine regeneration efforts accelerated rapidly and paper mills proliferated across the South. Planting and direct seeding reached a peak around 1959 , when over $1 \frac{112}{2}$ million acres were regenerated southwide (SFRAC 1959). Regeneration of the cutover lands and the determination of timber companies to protect their investments brought about an increase in the number of fences and stricter enforcement of trespass laws. Intensified fire protection and prescribed burning in young plantations reduced the threat of wildfire. Decrease in forage under the fast-growing pines forced many cattlemen to reduce their herds and some sold out completely. In the early 1960's, efforts were increased in southern National Forests to promote proper use of forage by strict regulation of cattle numbers. 


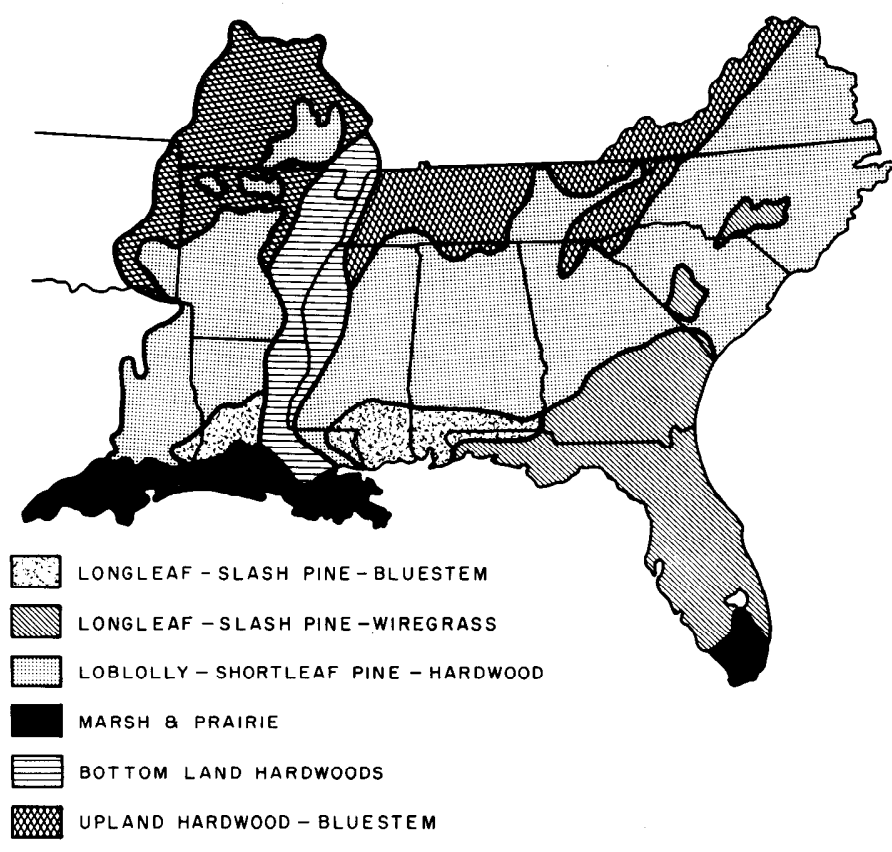

Fig. 1. Range types of the South (Byrd and Lewis 1976).

Total cattle numbers in the states shown in Figure 1 (excluding Texas and Oklahoma) rose from 6.8 million in 1900 to 9.5 million in 1940, an increase of about $40 \%$. In 1975, these states had 22.4 million cattle, more than twice the 1940 population. Improved productivity of cultivated pastures obviously accounts for much of this increase, despite the fact that there were about 1 million fewer acres of cultivated pastureland in 1974 than in 1940 ( 19.6 million acres). There was also a decrease in farm woodlands and woodland pasture, from 61.0 million acres in 1940 to 33.9 million in $1974 .^{1}$

Although some states do not yet have stock laws prohibiting free ranging of cattle on all land, the era of abundant, free grass and open-range grazing is over. Pines once again dominate the vast areas converted to grasslands by clearcutting of timber during the early part of this century.

\section{Research}

The earliest research on forest range in the South was conducted from 1923 to 1933 at McNeill, Mississippi, in a study of the effects of fire on longleaf pine (Pinus palustris Mill.) seedlings, soils, and grazing. Range burned annually produced $37 \%$ more cattle gains than similar unburned sites (Wahlenberg et al. 1939).

The importance of the southern livestock industry was apparent during World War II when the national demand for beef exceeded the supply. Surveys were conducted in North Carolina, Georgia, and Louisiana as a first step toward increasing beef production on forest range (Biswell et al. 1942; Biswell and Foster 1942; Campbell and Rhodes 1944). The surveys reported a low level of management among stockmen, who ran cattle (usually mixed with those of other operators) yearlong on open range. Calf crops averaged less than 50\%, with calves about 300 pounds at weaning. A later survey found similar conditions in south Alabama and west Florida among cattlemen who depended entirely on forest range. However, 75

${ }^{1}$ Cattle and acreage figures provided by the Bureau of the Census. to $80 \%$ calf crops and large calves were produced by progressive farmers who fed and managed their cattle well (Brasington 1948). A similar survey in East Texas indicated that half of the woods grazing was yearlong; the other half was seasonal, April through October. Calf crops averaged from 64 to $79 \%$ (Silker 1955).

Subsequent studies were designed to find the causes of and possible remedies for the problems revealed by the surveys. A study at the Coweeta Hydrologic Laboratory in the North Carolina mountains determined the hardwood browse preferences of cattle (Shepherd et al. 1946). Restricted breeding schedules were developed to insure that most calves are born in winter and could thereby take maximum advantage of lactation stimulated by the spring period of highest forage quality.

Better management began to show consistent results in the size and quality of calf crops. In research in Louisiana and Georgia, Brahman crossbred cows bred to goodquality Englishbreed bulls produced 80 to $85 \%$ calf crops and calves averaging 425 to 480 pounds at weaning (Duvall 1964; Halls et al. 1964). Of course, most cattlemen managed their herds far less intensively than research herds, thus potential production was seldom reached in typical operations.

A system of rotation burning was develped on pine-bluestem range in which one-third of each grazing unit is burned each year on a 3-year rotation (Duvall and Whitaker 1964). This rotates grazing much like a system with separate fenced pastures; utilization of herbage is high on the currently burned compartment and declines as other compartments are successively burned. On longleaf-slash pine-wiregrass range in Georgia, half of each research range unit was burned each year (Southwell and Hughes 1965). Such rotations allow pine seedlings to be planted in a 1 -year grass rough with a fresh burn nearby to attract cattle away from the young seedlings. When the entire range unit has been regenerated, burning must be curtailed until the oldest trees are large enough to withstand fire, usually about age 5.

Comparisons of the effects of 20 years of burning at various seasons and frequencies in a South Carolina loblolly pine forest indicated that burning every second or third winter produced good understory conditions for a combination of cattle and wildlife (Lewis and Harshbarger 1976). Recent investigations in Louisiana loblolly-shortleaf pine-hardwood forests show that capacities for yearlong grazing vary from 30 acres per cow to over 100 acres per cow, depending on the composition and density of the overstory (Wolters and Wilhite 1974).

Forage values of native grasses, forbs, and browse plants were determined and served as a basis for winter nutrient supplementation recommendations (Campbell and Cassady 1951; Cassady 1953; Biswell et al. 1943; Foster et al. 1945; Duncan 1958). With the supply of forage reduced because of pine regeneration and with the price of standard protein supplements high and rising, current research is concerned with finding a more economical method for supplementing range cows in winter. Liquid supplements, self-fed, show promise because they avoid the labor costs of hand-feeding (Pearson 1974). Wider use of improved pasture as winter supplement is anticipated, and pasture-range combinations are promising (Lewis and McCormick 1971).

A thorough evaluation of the extent of competition between cattle and deer for food plants is needed, particularly on loblolly-shortleaf pine-hardwood ranges. Evaluation should be made in stands where appreciable herbage production has been restored by thinning, timber stand improvement, and prescribed burning. 


\section{Major Forest Range Types}

Although grazing occurs in every forest type in the South, the former longleaf pine belt, now referred to in the Forest Survey as the longleaf-slash pine type, has always produced more understory herbage than other southern timber types. According to the most recent forest survey data of the U.S. Forest Service, the longleaf-slash pine forest type occupies over 18 million acres $^{2}$ of the lower Coastal Plain from east Texas to North Carolina. Longleaf pine alone originally occupied an estimated 30 to 60 million acres (Wahlenberg 1946). Range types generally correspond to timber types, but in range research the longleafslash pine forest type is categorized by the most abundant native forage grass in the understory. In Louisiana, Missisippi, Alabama, and northwest Florida, bluestem grasses (Andropogon spp.) dominate the herbaceous cover. On sandhills and pine flatwoods in Florida and Georgia, pineland threeawn or wiregrass (Aristida stricta Michx.), is usually dominant (Carter and Hughes 1974; Grelen 1974).

The other major range type, loblolly-shortleaf pine-hardwood, (including oak-pine and the loblolly-shortleaf pine timber types) (U.S. Forest Service 1969), occupies about 70 million acres of the upper Coastal Plain from east Texas and Oklahoma to Virginia (Fig. 1) and is the most widespread range type in the South.

Vast areas of bottom land hardwood forests still exist in the South, especially where the threat of frequent flooding discourages agriculture. Because of the scarcity of forage under dense hardwood stands, cattle may browse young hardwoods; thus grazing is generally considered incompatible with hardwood plantation management. Hardwood canopies, whether on bottom lands or uplands or as an understory in pine stands, usually produce too much shade to allow a substantial forage resource. Thousands of acres of low-quality hardwoods in southern Mississippi, western Arkansas, and eastern Oklahoma have been cleared by herbicides and converted to grasslands, either by recovery of native grasses or by planting fescue grasses (Festuca spp.) (Crawford and Porter 1974). Native and improved pasture acreage has increased within the pine types also.

A North Carolina survey revealed the potential value of switch cane (Arundinaria tecta (Walt.) Muhl.) as forage (Biswell and Foster 1942). Switch cane and giant cane (A. gigantea (Walt.) Muhl.) once furnished abundant nutritious forage on overflow bottoms and other low wet sites in the Atlantic and Gulf Coastal Plain to east Texas. In North Carolina, two acres of cane brakes on treeless low lands would support a cow from May to December (Shepherd 1946). Burning, heavy grazing, and clearing of the productive cane sites for cultivated crops have eliminated many acres of switch cane, and few extensive brakes are found today (Hughes 1966).

\section{Longleaf-Slash Pine-Bluestem Range}

This western section of the former longleaf pine belt comprises about 5 million acres from southwest Texas to the Florida panhandle. Bluestem grasses, primarily little bluestem (Andropogon scoparius Michx.) and its variety, pinehill bluestem ( $A$. scoparius var. divergens Anderss. ex Hack.), provide about half of the herbaceous forage on cutover lands and in frequently burned pine stands. Slender bluestem (A. tener (Nees) Kunth) may share dominance on burned and grazed cutover land, and creeping bluestem, (A. stolonifer (Nash) Hitchc.), a close relative of little bluestem, is abundant in Alabama and Florida.

Timber type acreages are compiled from individual state forest survey publications
Natural longleaf forests favor forage production, but current forestry practices are often geared to the faster growing and more easily regenerated slash and loblolly pines. In Louisiana, for example, less than 100,000 acres of the one million-plus acres of clearcut longleaf pinelands were restored to longleaf pine by 1965. Much cutover range has been planted to slash and loblolly (Foil and Merrifield 1966). Also loblolly pine is a more prolific seed producer than either longleaf or slash, and has invaded many cutover longleaf sites when annual burning was curtailed. About half of the available range on former longleaf pine sites in southwest Louisiana is being grazed and $80 \%$ of that is used only lightly (Sternitzke and Pearson 1974).

Prescribed burning, either for silvicultural purposes or as a range improvement practice, reduces number and size of understory shrubs and hardwoods (Fig. 2). West of the Mississippi

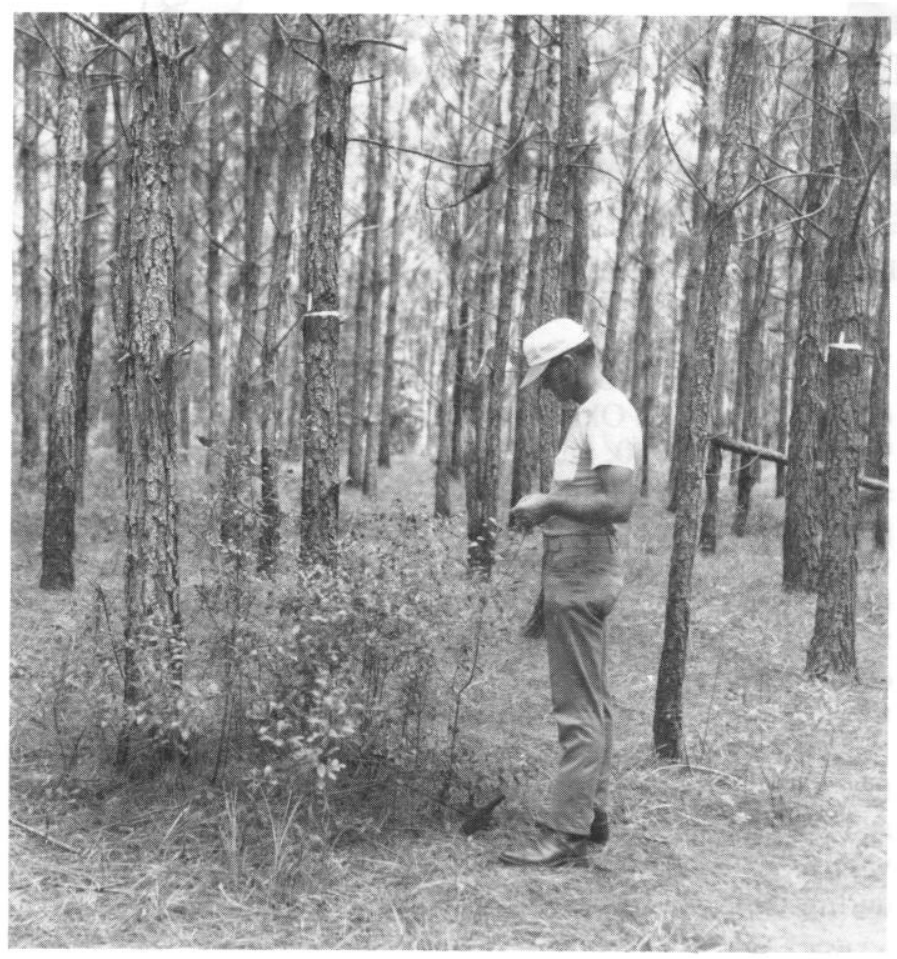

Fig. 2. Frequent prescribed fires kept the understory open in this 13-year-old slash pine plantation, but the pine overstory had reduced herbage production to about 300 lb/acre.

River, southern waxmyrtle (Myrica cerifera L.) is the most abundant understory plant of the range, interfering with forage production and grazing on unburned sites. Gallberry (Ilex glabra Walt.) is a common woody weed throughout the pineywoods east of the Mississippi River. It frequently forms dense understories on moist sites, reducing herbage yields and obstructing grazing. Southern red oak (Quercus falcata Michx.), blackjack oak (Q. marilandica Muenchh.), and post oak $(Q$. stellata Wagenh.) are common on most well-drained uplands and unless kept in check by frequent fires may produce dense shade in the understory. Regular burning does not eliminate shrubs and hardwoods but keeps plants within browsing reach of cattle and deer.

As young plantations mature, forage production varies with the management imposed; only if stands are thinned early and kept fairly open by frequent burning can a forage resource be maintained (Grelen 1976). Wolters (1973) found that in both slash and longleaf pine plantations herbage production declines 


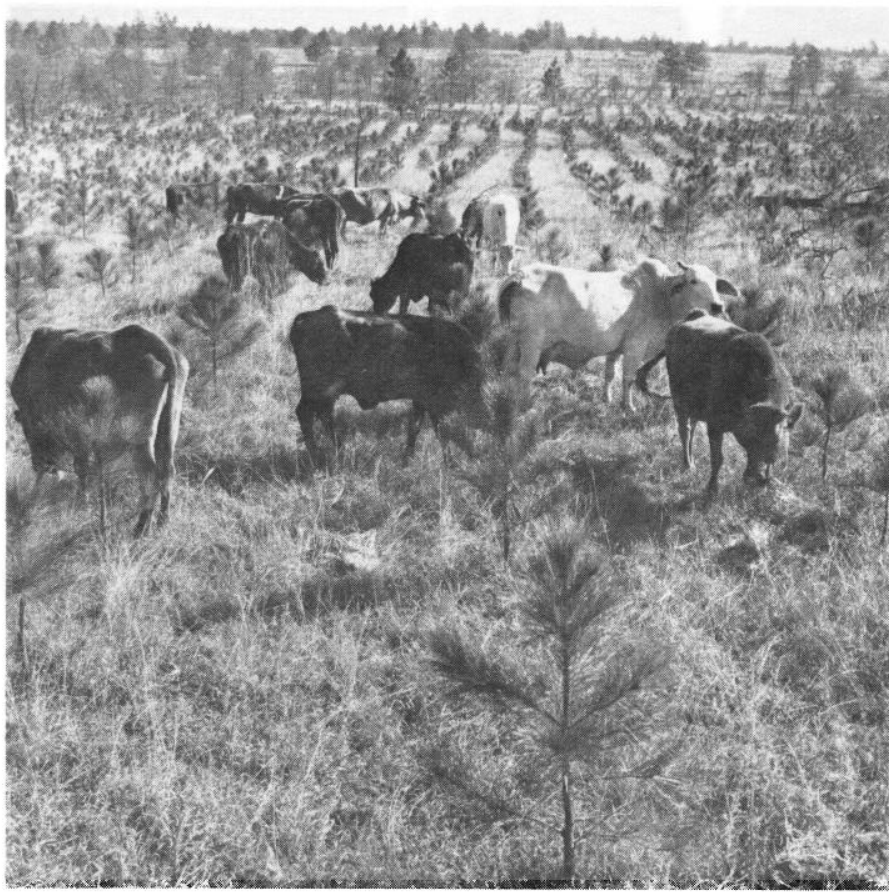

Fig. 3. Forage production in this 3-year-old slash plantation averages over a ton per acre annually, but yields will be reduced $50 \%$ by age 9.

$15 \mathrm{lb} /$ acre for each $1.0 \mathrm{ft}^{2} /$ acre increase in pine basal area (Fig. 3)

\section{Longleaf-Slash Pine-Wiregrass Range}

Over 13 million acres of the longleaf-slash pine range east of the longleaf-slash pine bluestem type are characterized by the presence of wiregrass, or pineland threeawn. Wiregrass is a tough bunchgrass that dominates the ground cover of dry sandhills and wet flatwoods and prairies of Florida and south Georgia. On the sandhills of northwest Florida, it is associated mainly with turkey oak (Quercus laevis Walt.), bluejack oak (Q. incana Bartr.), and scattered longleaf pines. Bluestem grasses are common but dominate sites only where the wiregrass rough has been removed. Once eliminated, wiregrass does not reestablish, but efforts to replace wiregrass with bluestems or other better forage grasses have been unsuccessful except when the wiregrass was mechanically eradicated.

As in longleaf-slash pine-bluestem range, prescribed burning is recommended. Saw palmetto (Serenoa repens (Bartr.) Small) and gallberry are top-killed by burning and can be held in check by burns every 3 to 4 years. Herbicide applications in August are effective but expensive (Halls et al. 1964).

Both the dry scrub oak sandhills and wet sandy flatwoods dominated by saw palmetto or gallberry are almost useless for growing trees or livestock (Fig. 4). Large areas of both types have been cleared for pine regeneration, and in south Florida many thousand acres of palmetto-dominated prairie have been cleared for grazing. Unique to south Florida are approximately 2 million acres of prairies that are too wet for pine stands of reasonable density (Rummell 1957). The land is used primarily for cattle ranching. When saw palmetto is removed by mechanical choppers, forage production from the native bluestem grasses is increased from as little as $150 \mathrm{lb} /$ acre to about 3 tons/acre (Yarlett 1965). Much of this prairie land is now in improved pasture.

\section{Loblolly-Shortleaf Pine-Hardwood Range}

Loblolly-shortleaf pine-hardwood range lies inland from longleaf-slash pine range (Fig. 1), and is characterized by uneven-aged stands of pines with a dense understory of hardwoods, shrubs, woody vines, and pine regeneration. Herbage yield is low unless the hardwood canopy is reduced by thinning and the understory is kept fairly open by regular burning. Throughout much of the type, bluestem grasses have been shaded out by the dense hardwood canopy, and the scant herbage consists of shade-tolerant, and often less palatable species such as spikegrasses (Uniola spp.).

Because herbaceous forage is relatively scarce, the type is more important for wildlife, particularly deer, than for cattle grazing. Cattle, especially those grazing yearlong, often depend on hardwood and shrub browse to supplement their diet. Where cattle heavily browse plants preferred by deer, both may suffer. Competition for forage can be alleviated by controlling cattle numbers and by thinning the forest overstory. Research is needed to determine the extent of competition and to find practical ways for resolving conflicts.

A recent increase in intensive site preparation for pine regeneration, particularly in the loblolly-shortleaf pine forest type, may enhance the grazing potential. Although severe mechanical denudation may destroy perennial grasses, other perhaps more nutritious herbage and woody sprouts abound while grasses recover. Both cattle and deer are attracted to these man-made openings in dense forests, and prevention of cattle damage to pine regeneration is a major problem.

\section{Management of Forage Resources}

Despite a long history of range management research by the Forest Service and the efforts of the Soil Conservation Service and other agencies to promote proper use, relatively few cattlemen manage the forest land their cattle graze. Forage production is dependent on timber management, and there is

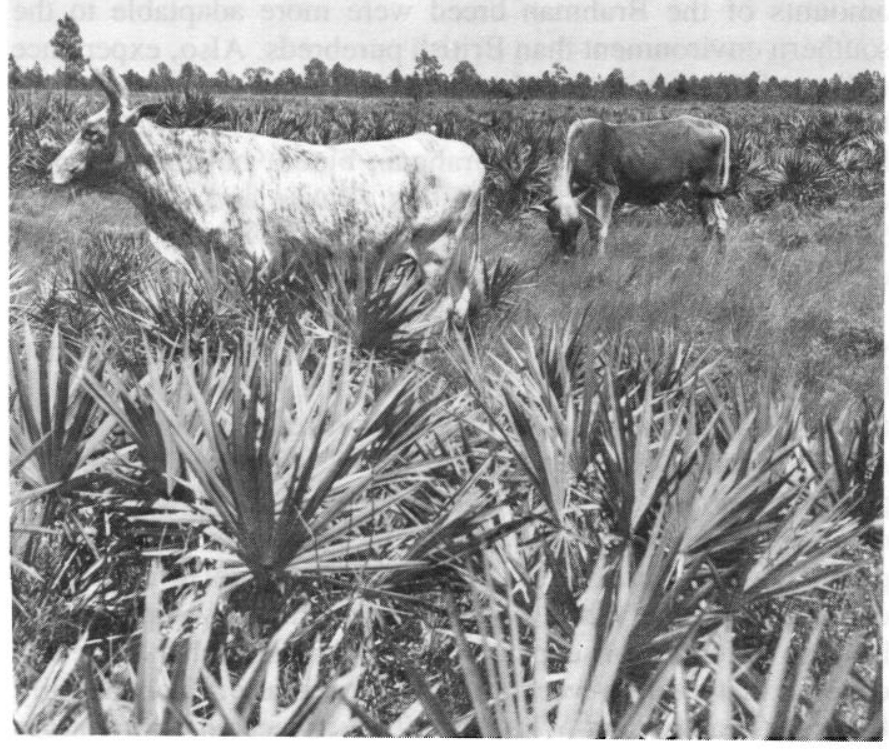

Fig. 4. Flatwoods sites in Georgia and Florida dominated by saw palmetto produce little forage; when the palmetto is eradicated, herbage yields up to 3 tons per acre are possible. 
little the cattleman can do to sustain or increase forage unless he owns the timber. Many small farmers with wood lots or tree farms successfully combine cattle and timber production. More often, practices such as burning to prevent damage by winter wildfires are carried out by timber management in late autumn or early winter, precluding winter grazing of forest range.

On southern National Forests appreciable grazing capacity has been maintained in natural stands of longleaf pine. On loblolly-shortleaf pine-hardwood range, where fire exclusion has produced dense understories of young pines, shrubs, and hardwoods, little herbage is produced and grazing is not encouraged. Even-age management of loblolly and shortleaf pine could improve forage resources if a way can be found to reduce concentration of cattle on clearcut regeneration areas.

Many cattlemen feel that they cannot afford to construct fences necessary to control range use properly on large tracts of National Forest or private timberland that their cattle graze, especially while permits are usually issued on an annual basis. Moreover, seldom will all cattlemen who have joint access to large tracts cooperate for mutual benefit. Attempts to form grazing associations of cattlemen using non-owned timberland have generally failed in the South. Long-term leases, rather than annual permits, would also encourage better management. When current land-use plans are completed, 10-year permits are planned for grazing allotments on National Forest Lands in Louisiana.

An apparent trend among large timber companies is to allow use of large tracts for hunting only. Some companies lease areas to hunting clubs, generating more revenue from the land than leasing the land for grazing. Hunting leases require no permanent changes or additions to the land such as water or fences. Much of the land best suited to hunting is not ideal cattle range, but most industrial land managers are not enthusiastic about forest grazing. Even on lands with abundant forage, they usually allow grazing only in the interest of public relations.

\section{Cattle Management}

The average range cow today, although still extremely heterogeneous, is larger and more productive than her ancestors. Cattlemen learned early that range cows with recognizable amounts of the Brahman breed were more adaptable to the southern environment than British purebreds. Also, experience indicated that a milk breed such as the Jersey greatly improves the Brahman crossbreeds (Whitaker et al. 1970). Many cows have a high percentage of Brahman blood, but the best producers usually have $50 \%$ or less (Baker and Black 1950; Southwell and Hughes 1965). Generally, however, no special effort is made to control the crossbreeding in range herds.

Traditional pineywoods range cattle operations involved yearlong grazing, with little or no winter food supplement. Cattle had to get winter protein from the leaves of evergreen trees and shrubs and the overwintering rosettes of certain forbs. As open range was fenced and better control of cattle was possible, more cattlemen began winter feeding. Cottonseed meal or cake, with a crude protein content of $41 \%$, was a popular winter supplement until the price doubled during the early 1970's. The labor required for feeding dry supplements has also become more expensive, although researchers have discovered that a thrice-weekly distribution is as efficient as daily feeding (Pearson and Whitaker 1972). Research with cottonseed meal mixed with salt to control intake has not proved satisfactory (Duvall 1969).

Many cattlemen now use liquid supplements, containing

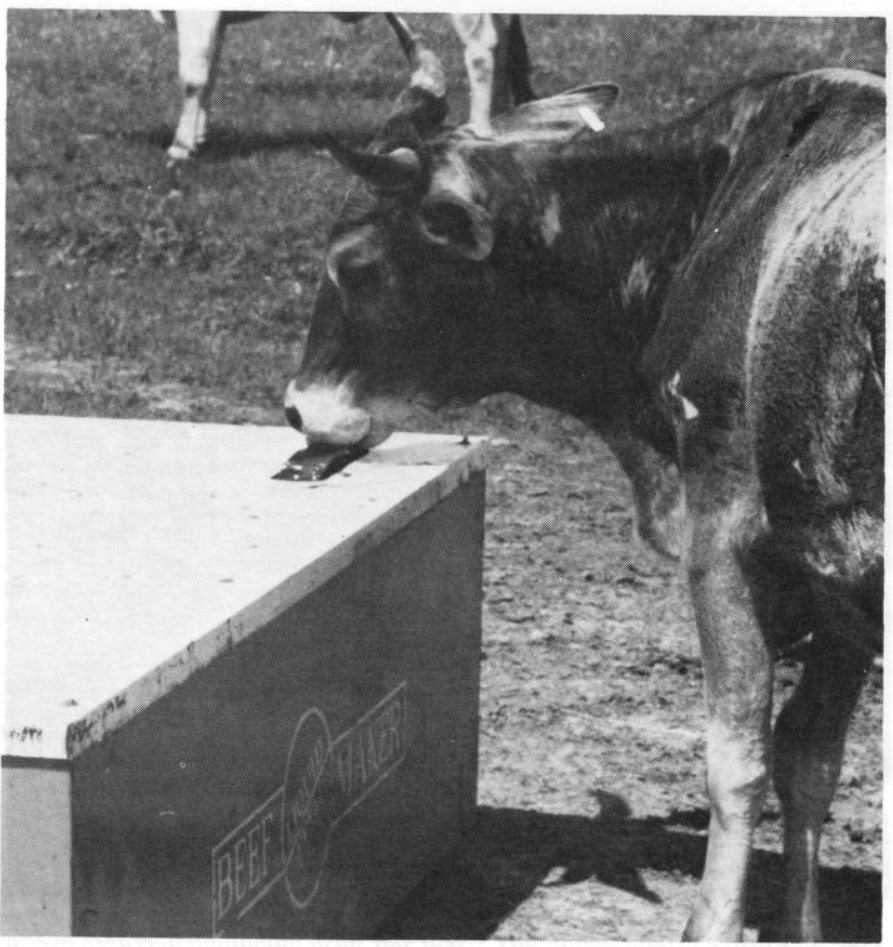

Fig. 5. Rising costs of natural protein supplements and feeding labor have caused many cattlemen to turn to urea-based liquid supplements which can be self-fed.

about $32 \%$ protein and dispensed free-choice in lick tanks (Fig. 5 ). Most of the protein in liquid supplements is provided by nonprotein nitrogen sources such as urea, with phosphorus and other minerals provided in balanced amounts. Best results are obtained when the supplement is made available to cattle yearlong. The cattleman who has to pay for labor to feed his cattle may find liquid supplements profitable, but if labor is not a consideration, feeding cattle cottonseed cake in winter may not be significantly more expensive (Pearson 1974).

Cattlemen who own or lease pasture land can use winter pasture or hay from summer crops as a winter supplement. However, grazing permits that prohibit winter grazing of forest range force permittees to provide enough land to support cattle in winter. Small improved pastures or grassed firebreaks interspersed within a grazed timber stand may be an efficient way to supplement feeding of brood cows in winter.

No follow-up has been made to determine the extent to which improved range livestock production practices have been adopted since early surveys outlined the severe management problems. Stock laws and increased range fencing have practically eliminated free-ranging cattle. The limited breeding season recommended by research has not been widely accepted, but the use of better beef-breed bulls is apparent. Small cattlemen who are in the business as a sideline to a regular job realize that they could increase returns by improving management but most are satisfied with present profits or feel they cannot afford additional investment.

\section{The Future of Forest Grazing}

The potential for range forage production in the South is probably greater than that of any other region of comparable size in the United States. However, dense pine stands on managed forest lands and even denser hardwood canopies on unmanaged land keep forage production far below the potential and it will 
probably decrease in the future.

Among factors that may affect future forest grazing, particularly in the loblolly-shortleaf-hardwood type, are complaints from sportsmen's groups that cattle compete with deer for browse, particularly during winter. The Forest Service is aware of the potential problem and advocates 7-month grazing on National Forest allotments where permittees have sufficient land to hold their cattle during the winter. Forest Service planners are also evaluating a deferred-rotation grazing system, which would allow cattle to remain on an allotment yearlong while excluding use on approximately one quarter of the allotment each year. The Soil Conservation Service in Louisiana recommends reserving 15 percent of the total livestock carrying capacity for deer.

Much forest land is lost each year to cropland and pasture, the urban sprawl, and real estate for private recreational use. The forage resource on much of the land still available for livestock grazing is declining as cleared areas are regenerated and pine and hardwood canopies shut out the sunlight needed for forage production. A drastic curtailment of prescribed burning, as has been proposed to maintain air quality, would insure further decline.

Most wildlife biologists and many foresters are intolerant of cattle in the woods; the attitude of timber company management and the stance of sportsmen, conservationists, and other groups often reflect this intolerance. Such opposition to forest grazing is likely to intensify. The average cattleman does little to enhance the image of forest grazing. He has no concept of proper use and will allow his cattle to overgraze, often unknowingly. He lacks the incentive or the financial means to invest in capital improvements or to cooperate with other cattlemen in grazing associations.

Until recently, range management research efforts in the South dealt primarily with cattle-herbage relationships. Greater emphasis is needed on the interrelationships of livestock with other multiple-use elements of forest management, particularly timber and wildlife. This can be accomplished by operationalscale multiple-use management research where compatibility of sound range management with other forest uses can be evaluated and results shown to livestock producers, timberland managers, wildlife biologists, and other environmentalists. Unless forest managers are convinced that maintaining a forage resource beneath their timber is profitable and compatible with timber production and other forest uses, especially wildlife, the attrition of forest range in the South appears likely to continue.

\section{Literature Cited}

Baker, A. L., and W. H. Black. 1950. Crossbred types of beef cattle for the Gulf Coast region. U.S. Dep. A_or. Circ. 844. 23 p

Biswell, H. H., and J. E. Foster. 1942. Forest grazing and beef cattle production in the Coastal Plain of North Carolina. N.C. Agr. Exp. Sta. Bull. 334. $22 \mathrm{p}$.

Biswell, H. H., B. L. Southwell, J. W. Stevenson, and W. O. Shepherd. 1942. Forest grazing and beef cattle production in the Coastal Plain of Georgia. Georgia Coastal Plain Exp. Sta. Circ. 8. 25 p.

Biswell, H. H., W. O. Shepherd, B. L. Southwell, and T. S. Boggess, Jr. 1943. Native forage plants of cutover forest lands in the Coastal Plain of Georgia. Gcorgia Coastal Plain Exp. Sta. Bull. 37. 43 p.

Brasington, J. J. 1948. Cattle grazing in south Alabama and west Florida forests. South Lumberman 177:183-186.

Byrd, N. A., and C. E. Lewis. 1976. Managing southern pine forests to produce forage for beef cattle. U.S. Forest Serv. State and Priv. Forest. Atlanta, Ga. Forest. Manage. Bull. Sept., 1976. 5 p.

Campbell, R. S., and J. T. Cassady. 1951. Grazing values for cattle on pine forest ranges in Louisiana. Louisiana Agr. Exp. Sta. Bull. 452. 31 p.
Campbell, R. S., and R. R. Rhodes. 1944. Forest grazing in relation to beef cattle production in Louisiana. Louisiana Agr. Exp. Sta. Bull. 380. 43 p.

Carter, Clifford W., and Ralph H. Hughes. 1974. Longleaf-slash pinewiregrass range. In: Range Resources of the South. Georgia Agr. Exp. Sta. Bull. NS 9. p 17-19.

Cassady, J. T. 1953. Herbage production on bluestem range in central Louisiana. J. Range Manage. 6:38-43.

Crawford, H. S., and I. R. Porter. 1974. Upland hardwood-bluestem range. In: Range Resources of the South. Georgia Agr. Exp. Sta. Bull. NS 9. p. 17-19.

Duncan, D. A., and E. A. Epps, Jr. 1958. Minor mineral elements and other nutrients on forest ranges in central Louisiana. Louisiana Agr. Exp. Sta. Bull. 516. 19 p.

Duvall, V. L. 1964. How much beef from native cows grazing forest range? Gulf Coast Cattleman 30(5):10-11, 14.

Duvall, V. L. 1969. Comparison of supplementation methods for cow herds grazing pine-bluestem range. J. Range Manage. 22:182-187.

Duvall, V. L., and L. B. Whitaker. 1964. Rotation burning: a forage management system for longleaf pine-bluestem ranges. J. Range Manage. 17: 322-326.

Foil, R. R., and R. G. Merrifield. 1966. Planted forests of Louisiana. Louisiana Agr. Exp. Sta. Bull. 611.48 p.

Foster, J. E., H. H. Biswell, and E. H. Hostetler. 1945. Comparison of different amounts of protein supplement for wintering beef cows on forest range in the southeastern coastal plain. J. Anim. Sci. 4:387-394.

Grelen, H. E. 1974. Longleaf-slash pine-bluestem range. In: Range Resources of the South. Georgia Agr. Exp. Sta. Bull. NS 9. p 9-12.

Grelen, H. E. 1976. Responses of herbage, pines, and hardwoods to early and delayed burning in a young slash pine plantation. J. Range Manage. 29:301-303

Grelen, H. E., and H. G. Enghardt. 1973. Burning and thinning maintain forage in a longleaf pine plantation. J. Forest. 71:419-420, 425.

Halls, L. K., R. H. Hughes, R. S. Rummell, and B. L. Southwell. 1964. Forage and cattle management in longleaf-slash pine forest. U.S. Dep. Agr. Farmers' Bull. 2198. 25 p.

Hughes, R. H. 1966. Fire ecology of canebrakes. Proc. 5th Annu. Tall Timbers Fire Ecol. Conf. p. 148-158.

Lewis, C. E. 1974. Southern ranges: an introduction. In: Range Resources of the South. Georgia Agr. Exp. Sta. Bull. NS 9. p. 5-8.

Lewis, C. E., and W. C. McCormick. 1971. Supplementing pine-wiregrass range with improved pasture in south Georgia. J. Range Manage. 24: 334-339.

Lewis, C. E., and T. J. Harshbarger. 1976. Shrub and herbaceous vegetation after 20 years of prescribed burning in the South Carolina Coastal Plain. J. Range Manage. 29:13-18

Pearson, H. A. 1974. Liquid supplements for cattle grazing native range. Proc. of the Program and 1973 Res. and Extension Progr. Rep. , Louisiana State University 14th Annu. Livestock Prod. Day. p. 33-40.

Pearson, H. A., and L. B. Whitaker. 1972. Thrice-weekly supplementation adequate for cows on pine-bluestem range. J. Range Manage. 25:315-316.

Riebold, R. J. 1971. The early history of wildfires and prescribed burning. In Proc. Prescribed Burning Symp. Southeast Forest Exp. Sta., Charleston, S.C. p. 11-20.

Rummell, R. S. 1957. Beef cattle production and range practices in south Florida. J. Range Manage. 10:71-78.

Silker, T. H. 1955. Forest grazing in the pine-hardwood and bottomland hardwood types of southeast Texas. Texas Forest. Serv. Bull. 47. 34 p.

Shepherd, W. O., C. M. Kaufman, and H. H. Biswell. 1946. Forest grazing in North Carolina. South. Lumberman 173:228, 230, 232, 234, 236, 238.

Southern Forest Resource Analysis Committee. 1969. The South's Third Forest . . . How It Can Meet Future Demands. $111 \mathrm{p}$

Southwell, B. L., and Ralph H. Hughes. 1965. Beef cattle management practices for wiregrass-pine ranges of Georgia. Georgia Agr. Exp. Sta. Bull. NS 129.26 p.

Sternitzke, H. S., and H. A. Pearson. 1974. Forest-range resource statistics for southwest Louisiana parishes. U.S. Forest. Serv. South. Forest Exp. Sta. New Orleans, La. Resour. Bull. SO-50. 22 p.

U.S. Forest Service. 1969. A forest atlas of the South. South Forest. Exp. Sta and Southeast Forest Exp. Sta. 27 p.

Van Houweling, C. D. 1956. Our battle against animal disease. In: Animal Diseases. U.S. Dep. Agr. Yearb. of Agr. 1956. p. 1-7.

Wahlenberg, W. G. 1946. Longleaf pine, its use, ecology, regeneration, protection, growth, and management. Charles Lathrop Pack Forestry Foundation, Washington, D.C. 429 p.

Wahlenberg, W. G., S. W. Greene, and H. R. Reed. 1939. Effects of fire and cattle grazing on longleaf pine lands, as studies at McNeill, Miss. U.S. Dep. Agr. Tech. Bull. 683. 52 p.

Whitaker, L. B., H. A. Pearson, and W. M. Monroe. 1970. Crossbred 
cattle-custom-built for piney woods range. Louisiana Cattleman 70:8-9. Wolters, G. L. 1973. Southern pine overstories influence herbage quality. J. Range Manage. 26:423-426.

Wolters, G. L., and A. T. Wilhite, Jr. 1974. Loblolly-shortleaf pine- hardwood range. In: Range Resources of the South. Georgia Agr. Exp. Sta. Bull. NS 9:20-23.

Yarlett, L. L. 1965. Control of saw palmetto and recovery of native grasses. J. Range Manage. 18:344-345. 